\title{
逆転移行課題での反応樣式とパーフォマンス に及漹す媒介活性化教示の効果
}

\author{
九 州大 学 ${ }^{1}$ \\ 丸 野 俊 - ${ }^{2}$

\section{THE EFFECT OF MEDIATION-GENERATIVE INSTRUCTIONS UPON THE PERFORMANCE AND LEARNING MODES IN REVERSAL SHIFT}

\section{SYUNICHI MARUNO}

\author{
Kyushu University
}

\begin{abstract}
The purpose of the present study was to investigate the effect of mediation-generative instructions upon the performance and learning modes in reversal shift with verbal materials. Prior-instructions were given to Ss as follows: (a) Instructions to generate a visual image of the stimulus pair member (Verbal), (b) presentation of the picture of the stimulus pair member (Pictorial), (c) the presentation and the instructions were given together (Pictorial-Verbal), or (d) neither Pictorial nor Verbal instructions were given (Control). In the Pictorial-Verbal, Verbal, Pictorial groups (in order), the mediational mode responses (conceptual, response-switching learning. mode) were found more numerous than the associative learning mode, while in the Control group the inverse was true. In the group that efficient mediational mode responses were found more numerous, the shift problem was easy. These results were interpreted in terms of the depth of information-processing of Ss.
\end{abstract}

逆転移行学習場面に直面した児童や大人は，移行過程 において，原学習で形成されたある次元に対する表象反 応を媒介にして，外的刺激と外的反応間の連合を形成す ると考觉られてきた (Kendler \& Kendler, 1970).

（例えば，原学習で黒い三角形（黒三角）と赤い三角形 （赤三角）が正刺激であったものが，移行学習では，原 学習で負刺激であった赤い四角形（赤四角）と黒い四角 形 (黒四角) が正刺激になる。このような逆䎐移行学習 飞扔いて児童や大人は，原学習で形成された形次元を媒 介子にして移行学習時の外的反応をコントロールすると みなされてきた)。 また，従来多くの研究者は，ぞの年 齢段階に達すると媒介反応様式にもとづく学習が可能に なるのか，ぞのような実験パラダイムがよりよく媒介過 程での表象反応の役割学查定できるかといった問題に焦 点をあて，乙かもある年龄段階をすぎると全ての被験者 が上述のような媒介型の学習様式を取るものと暗黙裡の らちに認め, 同じ発達段階に方る被験者側の学習型を分 析することに注意を払ってこなかったように思われる。

1 現所属 山形大学.

2 本研究を御指導下さった九州大学教育学部助教授山 内光哉先生泟厚く感謝します。
しかしながらごく最近になって, Cole (1973) も指摘 しているように，研究の方向が，“媒介反応様式は刺激 変数, 教示, 実験手続き (ex. 継時提示, 同時提示), や被験者の過去経験によってどのように異なるか”とい った問題を解明しようとする方向に変化してきている.

ところで, 確かに, 先述のような逆転移行場面に拈い ては，形次元とか色次元を媒介とした学習が可能である が，媒介型の学習様式を取る発達段階にあると思われる 被験者の全てが，実際に次元性にもとづく媒介反応様式 を取るのであららか。移行過程に招いて，次元性にると づく媒介学習を行なうことができるためには，被験者 は，原学習完成時に黑三角と赤三角の正刺激から形次元 が適切次元で，色次元が不適切次元になっていることを 識別していなくてはならない，多くの被験者の中には， 黒三角と赤三角が正刺激で黒四角と赤四角が負刺激であ ることは識別していても，何が適切次元で，何が不適切 次元であるかを分化識別していない被験者がいることが

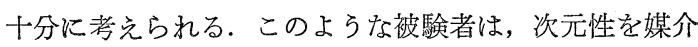
とした学習様式を取ることができない，もしそのような 被験者が論理的思考の発達した年齢段階にあるならば, たとえ適切次元を抽出し，それを媒介とした学習を行な 
うことができなかったとしても，刺激を主体的に体制化 乙（例兄ば，正刺激の仲間，負刺激の仲間とい5上5 全刺激事象を 2 つの下位セット乣分化する. 移行学習で は同じセット関係を維持しつつ選択反応を逆にしさえす ればよい), “逆にする”という論理的操作によって移行 学習を行ならことができる可能性が, この逆転移行場面 飞は存在している.

最近, その可能性を示唆している研究が行なわれた (Bogartz, 1965 ; Goulet \& Williams, 1970). 彼らは, 次元性を欠いた無意味経りを用いて逆転・半逆転移行学 習を比較し逆転学習が容易であることを見出した，そし て, この半逆転に対する逆転学習の容易な結果を“逆を 行なら” (doing the opposite) という仮説にもとづき説 明した。

一方, 丸野(1973)は, 次元性を含んだ言語材料での逆 転移行学習に执いても，適切次元を抽出できなかった多 くの被験者は “逆にする”といら論理的操作によって移 行学習を行ならといら結果を示した. さらに Maruno （1974，1975）は, 逆転移行過程時に括ける反応梯式の 分析を詳細に行ない, 被験者は原学習終了時での自分の 情報処理のレベルにあった反応様式，すなわち概念的反 応様式 (次元性を媒介にした反応様式), 逆反応様式 (反 応をまったく逆にするという一種の媒介反応様式), 連 合的反応様式（強化された刺激を 1 個 1 個覚光学習して いく反応様式）のぞれかを用いて移行課題を遂行してい るといら結果を示した. これら一連の結果は, たと光次 元性の利用可能な学習課題が与えられたとしても, その 課題構造を十分把握したらえで逆転移行課題遂行に一番 効率的な媒介型の学習様式を利用できるか否かは, 被験 者の原学習終了時での情報処理の水準によって異なるこ とを示唆している.

上述のように被験者側の学習型に注目すると, 次元性 にもとづく媒介型の学習样式を利用することが可能な発 達段階にある被験者に “なぜ, 移行過程に招いて，3 3 反 応様式（概念的, 逆反応, 連合的反応椂式）が見出され たのだろらか”といら新たな問題が生じてくる. この問 題に対して考兄られる可能なひとつの説明として Maruno (1975b)は, 被験者の内省報告とパーフォマンス

3 丸野(1975a) 被験者の選択していく手がかりをチ エック乙同時に内省報告をる考虑しつつ, このよ5な説明 （仮説）の妥当性を実際のパーフォマンスから示唆した. それによると, 被験者は移行学習の第 1 試行目には原学 習の最終試行で維持していた仮説検証行動のもとに反応 しょうとする。つまり原学習の最終試行に特いて次元性 にもとづく仮説検証行動をしている被験者は，移行学習 課題にはいってもまずその仮説領域の中の刺激項目を選 択していく. 一方, 原学習の最終試行に拈いて次元性にも とづく仮説検証行動のできていない被験者は, 移行学習 《はいって子試行錯誤的, 連合的反応様式を用いている.
の関係から次のように解釈した．被験者が，移行過程に 抢いていかなる反応様式を利用するかは原学習完成時の 情報処理の水準に依存しているのではないかと童. 従っ $\tau$, 移行過程時飞連合的, 逆反応, 概念的反応様式を利 用した被験者は, 原学習基準達成時の情報処理の水準が 以下のようなそれぞれの水準まで進行していたのではな いかと解釈した．それぞれの情報処理の水準とは，(a) 被験者は，ぬだ適切な刺激次元を識別できず，完全に刺 激対象の分化が進行していない水準にある. この水準で は，学習は反応と強化の随伴性によって成立していると いえる. 具体的に言光ば, 被験者は, 赤三角, 黒四角之 いらように 2 次元の次元間の分化を行なって括らず，融 合した状態で刺激を認知し学習している水準にある.

（b）被験者は，適切な刺激次元を分化識別している水 準にまだ至っていない，乙かし（a）水準とは異なり， 強化された刺激を選択するという共通反応の連合を通し て全刺激事象を強化刺激セットと非強化刺激セットの 2 つのセットに分化している水準にある。しかしながら強 化刺激七ット, 非強化刺激七ットからそれぞれ適切次 元，不適切次元を抽出するまでの水準にいたっていな い.（c）被験者は, 適切な刺激次元を抽出している水 準にある.この水準では, 適切次元にもとづいてある刺 激を他の刺激から識別しているといえる。すなわち，刺 激煌まれている2次元は，それぞれ独立に变化する次 元として区別されている.

さらに，このような見解に加光て，Maruno (1975b) は, 移行過程時での概念的反応様式の利用者が年龄の関 数として増加し, 連合的反応椂式の利用者が減少した結 果から次のように推測した。すすなわち, どのよらな反応 様式穵利用するかは被験者間で, また発達的にも異なっ て和り, そのような差異は, 被験者の認知的経験ならび に学習能力, 特に与兄られた情報を効果的に処理する能 力のちがいに依存しているのではないかと.つまり, 原 学習終了時での情報処理（課題構造把握の程度）が不十 分な被験者は, 実験者の意図している適切次元（仮説） をまだ同定していないがゆえに，移行過程時では効率的 な媒介反応様式を利用できず連合的反応椂式をとらざる をえないと。

そこで, 今, るしある課題での適切次元を分化識別し 利用する可能性を高めるよらな条件 (例光ば, 教示, 先 行訓練）が, 被験者に与兄られるならばいかなる結果が 生じるであららか. 多くの仮説を持って学習場面にはい ってくる被験者は, 上述のような条件が与えられること によって実験者の意図しているような仮説行動のもとに 課題を遂行することが可能になり, その結果, 移行過程 に怙いては効率のよい媒介反応樣式を利用する被騟者が 増加することが予想される.この論文は，この予想を検 討するために企画された。すなおち，丸野 $(1973,1974$, 
1975 b) と同じように 2 次元を含んだ言語材料（ここで は形, 色次元といった，いわば知覚的側面が適切次元に なっている. 従って意味的・機能的側面での仮説を立て がちな被験者にとってはなかなか実験者の意図している 適切次元を同定できない困難な課題である）での逆転移 行課題を行なら前に, 先行教示条件として, 知覚的側面 をイメージ化するよらな言語教示, 知覚的刺激提示 (各 言語刺激を 1 枚 1 枚描画したものを提示), 言語教示十 知覚的刺激提示を行なら。このような実験条件が与兄ら れることによって, 被験者は実験者の意図している課題 構造を把握でき，そこに含をれている適切次元，不適切 次元を分化識別できるのではないかと容易に予測するこ とができる，この予測のもとに，上述の 3 実験条件群 は, 統制群に比較して原学習, 移行学習での学習は容易 になり，かつ移行過程に物いては效率的な媒介反応様式 を利用する者が增加するという仮説がたてられる。

\section{方法}

被験者 被験者は中学 2 年生 100 名（男子 55 名, 女 子 45 名）である.これら 100 名の被験者は, 後に示す 言語教示群, 絵画提示群, 言語教示十絵画提示群, 統制 群のそれぞれに 25 名ずつ割り当てられた. 上述の 100 名以外の 12 名, すなわら言語教示群の 2 名, 絵画提示群 の 3 名, 言語教示十絵画提示群の 2 名, それに統制群の 5 名は, 原学習での 50 試行以内に和いて 10 連続正反応 の基準に達することができなかったのでその後の実験か ら除去された。

実験材料 丸野 $(1973 ， 1974)$ と同じように 2 次元 （色，形）を同時に含んでいる 8 単語，すなわちタイヤ (黒・円)，とうら (白・四角), 黒板 (黒・四角), た末 ご（白・円），バレーボール（白・円），レコード（黑・ 円), はがき (白・四角), すずり (黒・四角) が用いら れた. これらの単語は，2次元が同時に変化するよらに 対にされ $9 \times 20 \mathrm{~cm}$ の白色カードにプリントされた，従 って白・四角の対象を示す言語刺激は，いつ子黒・円の 対象を表わす言語刺激と対にされたことになる。このよ らな条件のもとに構成された 80 枚の刺激カードは，同 刺激対のカードが 2 回以上連続して提示されないよう に, また正刺激の左右の位置がランダムになるように再 構成された.

手続き 実験は, 先行教示, 弁別課題, 反応様式の分 類のための面接質問の 3 位相から成立している。

先行教示 先行教示条件として（1）言語教示群，(2) 絵画提示群,（3）言語教示十絵画提示群，（4）統制群が 設定された.

（1）言語教示群 (以下V群): 実験者の意図してい るような課題構造の把握を被験者に暗示するために次の ような教示が与えられた。 “ここに 8 単語があります。
今，ひとつひとつの単語を提示（文字で提示）しますか ら，それがぞのようなものかまずイメージを浮かべて下 さい.それでは，この単語（例壳ば黒板）はどんな色， 形をしていますか”。このような言語教示のもとに8 単 語のイメージを次々に浮かべさせ，そして色，形の知覚 的側面に注意を集中させた. しかしながら被験者の反応 に対しては，いかなる情報も与えなかった。

（2）絵画提示群（以下P群）：(1) と同じ目的のた めに“ここに 8 枚の絵があります。.よく見て下さい。何 が描いてあるかわかりますね”という教示のもとに，上 述の 8 単語が示す対象をひとつひとつ 1 枚の刺激カード $(10 \times 10 \mathrm{~cm}$ の白色カード) に描画したもの（その際， 色，形は明確に描画した）をみせた，ただし，この群は 描画刺激だけで，それを示す単語は示されない。

（3）言語教示十絵画提示群（以下 PV 群）: (1), (2) と同じ目的のために (1) 条件と（2）条件を組み合わせた 群である。すなわら“ここに 8 単語があります。今，ひ とつひとつの単語を提示しますから，それがどのような るのかまずイメージを浮か心゙て下さい”と教示した後, “今度は，それら8 単語が示す対象を描画した刺激カー ドを 1 枚 1 枚提示しますから，めなたの浮かべたイメー ジと一致しているところがあるかどうかよくみて下さ い”と教示し知覚的側面を浮きぼりにした絵画刺激を提 示した。

（4）統制群（以下 C 群）：実験者の意図しているよ らな課題構造の把握を被験者に暗示するための先行教示 条件はなんら与兄れなかった。

以上， 3 実験条件群と統制群とが設定されたのである が，どちらかといえば，(1) 群は, 被験者がイメージし たものそのものから実験者の意図している課題構造を把 握する群で, (2) 群は, 課題構造把握への方向に実験者 から積極的に注意を向けさせられる群であり, (1) 群に 比較してこの群は, 実験者の意図している仮説（概念） を同定しやすいのではないかと予想される。（3）群は， （1）群と（2）群を組合せた群であり，この 3 群の中では 一番課題構造把握の水準が高く, その結果, 移行過程で は媒介反応様式の利用者が一番多くなると予想される.

弁別問題 4 群とも通常の弁別手続さと同じように “ここに単語の書いたカードがあります。このうちどら らか一方がいつも“あたり’と決めてあります，当りと 思う方声法して言って下さい。もしそれが当ってい れば‘あたり’と言い, はずれていれば‘はずれ’と言 い屯すので，できるだけ多く“あたり’と言われるょう にして下さい”と教示され原学習課題が与えられた. 原 学習に招いては, 各下位群が白と黒, 四角形と円をとれ ぞれ正刺激として学習させられた.つまり各群の被験者 の半数が色を適切な次元とし, 残りの半数は形を適切な 次元として学習したことになる。原学習において，50試 行以内に 10 連続正反応の基準に達することのできなか 
TABLE 1

Mean numbers of trials $(\sqrt{X+0.5}$ transformed scores) to criterion in the original and shift problems

\begin{tabular}{c|cccc|c}
\hline & $\begin{array}{c}\text { P V } \\
\text { group }\end{array}$ & $\begin{array}{c}\mathrm{P} \\
\text { group }\end{array}$ & $\begin{array}{c}\mathrm{V} \\
\text { group }\end{array}$ & $\begin{array}{c}\mathrm{C} \\
\text { group }\end{array}$ & Mean \\
\hline Original & 1.99 & 3.04 & 2.92 & 3.35 & 2.83 \\
Shift & 1.45 & 1.91 & 1.77 & 2.55 & 1.92
\end{tabular}

った者 12 名を除き, 他の者は, 基準に達すると引き続 きなんらの情報も与えられず移行課題に移った，ここで の手続き並びに学習基準は原学習と同じであった。な特 移行学習飞扮いて 50 試行以内に 10 連続正反応の基準に 達することのできなかった者はひとりもいなかった，従 って原学習の成立した者は, 皆移行学習を遂行したこと になる。

反応様式を分類する方法 移行過程に和いて，被験者 がいかなる反応梯式を利用したかを分析する観点から， 全被験者を，次元性にもとづく媒介反応様式を利用した もの（概念的反応㥞式群），次元性を媒介とすることな く“逆を行なら’という一種の媒介反応様式を取った者 (逆反応様式群), 反応之強化の随伴性による反応様式を 取った者（連合的反応様式群）に分類するため，移行学 習終了後，個別に面接質問を行なった，使用された質問 項目は下記のと祅りである。

1. ‘市たりの刺激”が学習している間変化したのに 気づきましたか.

2. 変化前では, また変化後ではどのような仲間が “あたり’でしたか（ここで被験者が共通概念を報告す れば問題ないが，もし単に正刺激の仲間（例学ば，たま ご・タイヤ・レコード・バレーボール）を報告した場合 には次の質問項目 3 が与兄られた).

3.これらの単語はどんな仲間ですか（ここで，もし 被験者が共通概念（ex. 四角形の仲間）を報告した場合 には,さらに次の質問項目 4 が与兄られた).

4. 岁なたは，それ（共通概念）を学習中に気づいて い屯したか，それとも私（実験者）の質問後にはじめて 気づきましたか（もし被験者が共通概念を学習中に気づ いていたと報告したならば，その被験者は概念的反応様 式群に分類された。 しかし実験者の質問後にはじめてそ れに気づいたと報告したならば，その被験者は，次の質 問項目 5 との関係に捻いて逆反応様式群か連合的反応様 式群かのどちらかに分類された).

これまでの質問項目 2-4 亿対して, 被験者が適切な 言語報告をしなかったならば，次の質問項目 5 が与兄ら れた。

5.あなたは，どのように学習していきましたか。
TABLE 2

Numbers of Ss of Conceptual, Response-switching, and Associative learning mode groups in all four conditions

\begin{tabular}{c|ccc|c}
\hline Condition & Concept $\begin{array}{c}\text { Response- } \\
\text { switching }\end{array}$ & $\begin{array}{c}\text { Associa- } \\
\text { tion }\end{array}$ & Total \\
\hline P V & 20 & 5 & 0 & 25 \\
P & 13 & 8 & 4 & 25 \\
V & 15 & 8 & 2 & 25 \\
C & 10 & 8 & 7 & 25 \\
\hline Total & 58 & 29 & 13 & 100
\end{tabular}

Note. PV : Pictorial-Verbal group. P: Pictorial group. V: Verbal group. C : Control group.

これら 5 つの質問項目の結果から被験者を 3 群に分類 する，その分類基準は以下のと招りである。概念的反応 様式群の基準は, 強化刺激に共通な概念の報告, すなわ ち次元性にもとづく媒介反応椂式を報告した場 合であ る. 逆反応様式群の基準は, 共通概念には気づいていな いが強化刺激セット項目を明確に報告し，かつ“反対に した’といら様式を用いたことを報告した場合である。 連合的反応様式群とは，機能的反応様式（次元性飞ると ら゙く媒介反応様式や“逆を行なう’という一種の媒介反 応椂式を報告することなく, 強化された刺激を 1 つ 1 つ 覚光ていったという内容を報告した群である。な和，実 験がすべて終了した後, すべての被験者が刺激単語に対 して一貫性のある形，色を意識していたかどうかを知る ために “これらの単語が示す内容は，どんな色，形です がといら質問を行なった. この質問に対しては, すべ ての被験者が一貫性の方る報告（例光ば白・四角）を示 した.

\section{結果}

基準までの平均試行数が反応測度として用いられた. Table 1 には, 原学習, 移行学習での基準達成までの $\sqrt{X+0.5}$ 変換平均試行数が示されている.

原学習 基準達成までの変換平均試行数について分散 分析が行なわれた結果有意な変動がみられた $\left(F_{(3,91)}=\right.$ 4.09, p<.01). そこで, ぞのグループとどのグループ との間に有意な変動がみられたのかを比較するために Tukey test が行なわれた. その結果, $\mathrm{PV}$ 群と $\mathrm{C}$ 群と の間 $\left(q_{(4,25)}=1.34, \quad p<.05\right), \quad \mathrm{PV}$ 群と $\mathrm{P}$ 群との間 $\left(q_{(3,25)}=1.05, p<.05\right)$ 飞有意美がみられ, PV 群は C 群よりも, 㷊た PV 群はP 群よりも学習が容易である ことが示された。 また PV 群とV群との間に傾向がみ られた $\left(q_{(2,25)}=.93, .05<p<.10\right)$ が，その他のグルー プ間澺差はみられなかった.

移行学習 原学習での分析と同じように, 基準までの 


\section{TABLE 3}

Mean numbers of trials $(\sqrt{X+0.5}$ transformed scores) to criterion of Conceptual, Responseswitching, and Associative learning mode groups in the original problem

\begin{tabular}{|c|c|c|c|}
\hline Condition & Concept & $\begin{array}{l}\text { Response- } \\
\text { switching }\end{array}$ & Association \\
\hline PV group & 1.56 & 3.74 & - \\
\hline group & 1.91 & 4. 16 & 4.59 \\
\hline group & 2. 22 & 3. 96 & 5.57 \\
\hline C group & 2.19 & 4. 43 & 3.96 \\
\hline Mean & 1.92 & 4.11 & 4. 41 \\
\hline
\end{tabular}

変換平均試行数についての分散分析の結果有意差がみら れた $\left(F_{(3,96)}=5.07, p<.01\right)$. 従ってグループ間の差異 を検討するために Tukey test を行なった. その結果, $\mathrm{PV}$ 群と C 群の間 $\left(q_{(4,25)}=1.10, p<.01\right), \mathrm{V}$ 群と C 群 の間 $\left(q_{(3,25)}=.78, p<.05\right)$ に有意な変動がみられ $\mathrm{PV}$ 群はC 群よりも, またV 群はC 群よりも学習が容易であ ることが示された.さらに $\mathrm{P}$ 群と $\mathrm{C}$ 群との間 $\left(q_{(2,25)}=\right.$ $.64, .05<p<.10)$ には傾向がみられたが, その他のグ ループ間には有意な変動はみられなかった.

反応様式の分類 被験者のパーフォマンスを知らない 2 人の評定者が，質問紙の回答の結果から被験者を概念 的, 逆反応, 連合的反応様式のぞれかに分類した. その 結果が Table 2 に示してある. Table 2 からもわかる ように, 各条件群にそれぞれ概念的, 逆反応, 連合的反 応様式がみられた，今，各条件群に和けるそれぞれの反 応様式の出現頻度をみると, 先行条件によって実験者の 意図している課題構造把握への構えが形成されたと思わ れる $\mathrm{PV}$ 群, $\mathrm{V}$ 群, $\mathrm{P}$ 群（その中でも特に $\mathrm{PV}$ 群にお いては著しいのであるが）には, 概念的反応椂式が連合 的反応様式よりも多く見い出されている，逆に，そのよ らな条件が与えられずなかなか実験者の意図している適 切次元（仮説）を同定できなかったと思われるC 群で は, 概念的反応様式と連合的反応様式の頻度数の間に大 差がみられない. 実際に, 各条件群と反応様式の出現頻 度の関係をみるため, Table 2 の数值にもとづく $\chi^{2}$ 検 定を行なった結果, 全体として有意差が㕛られた（ $\chi^{2}{ }^{(s)}$ $=8.70, p<.05)^{4}$. 従って, 各条件群に打ける反応様式 の出現頻度に差が認められたので, 各 2 条件群間の反応 様式の出現頻度を検定した結果, PV 群と C群との間に 有意差がみられ $\left(\chi^{2}{ }_{(1)}=8.33, p<.01\right), \mathrm{C}$ 群に比較し

44 (先行教示条件) $\times 3$ (方略) の $\chi^{2}$ 検定を行な5つ もりであったが, 理論度数 5 以下の細胞数が全体の 20 \%を越えたので, 4 (先行教示条件) $\times 2$ [概念・非概念 (連合十逆反応方略) ] の $\chi^{2}$ 検定を行なった。
TABLE 4

Mean numbers of trials $(\sqrt{X+0.5}$ transformed scores) to criterion of Conceptual, Responseswitching, and Associative learning mode group in the shift problem

\begin{tabular}{|c|c|c|c|c|}
\hline \multicolumn{2}{|c|}{ Condition } & Concept & Response- & Association \\
\hline PV & group & 1.41 & 1.69 & - \\
\hline $\mathrm{P}$ & group & 1.51 & 1.56 & 3.91 \\
\hline V & group & 1.44 & 1.73 & 4.34 \\
\hline $\mathrm{C}$ & group & 1.61 & 1.85 & 4. 82 \\
\hline & & 1.47 & 1.71 & 4. 46 \\
\hline
\end{tabular}

て PV 群には概念的反応様式の利用者が有意に多いこ とが示された。しかしその他のグループ間には有意差は 見出されなかった.

概念的, 逆反応, 連合的反応様式群の原学習での成績

Table 2 からもわかるように移行過程に和いて, 被験 者は様々の反応様式を利用することが示されたが，移行 過程時に概念的, 逆反応, 連合的反応様式を利用した被 験者は，それぞれ原学㖬では，どのよらなパーフォマン スを示していたのであろらか. この観点に立って Table 1 に表わされている各条件群の原学習での成績を再分類 した結果が Table 3 に示されている. この Table 3 の 数值については, Table 2 に示されているよらに, 細胞 内の度数があまりにも少ないところがいくつかあるため に 3 (反応様式の分類) $\times 4$ (教示条件) の分散分析を行な わず，各条件群の中のそれぞれの反応様式群の成績を結 合し，1 要因分散分析を行なった. その結果，有意な変 動がみられた $\left(F_{(2,97)}=68.13, p<.001\right)$. そこで，どの 反応様式群とどの反応様式群との間に有意差がみられた のかを検定するために Tukey test を行なった. その結 果, 概念的反応様式群と連合的反応様式群の間 $(p<$ $.001)$, 概念的反応様式群と逆反応様式群の間 $(p<.001)$ に有意差がみられ, 概念的反応様式群は連合的反応様式 群よりる，かつ逆反応様式群よりも容易に原学習を行な っていたことが示された. しかしながら, 逆反応様式群 と連合的反応様式群との間には有意差はみられず, 両群 はほぼ同じ速度で原学習を遂行していたことがわかっ た。

概念的, 逆反応, 連合的反応様式群の移行学習での成績

概念的反応様式と同じように一種の媒介反応とみなさ れる（丸野，1973，1974）逆反応様式を利用した被験者 は，そのよらな媒介反応様式を利用することのできなか った連合的反応様式群よりも移行学習は容易であること が予想されるが果してどらであろらか.この観点のもと に Table 1 の移行学習の結果を, それぞれの反応様式 
群にもとづき再分類した結果が Table 4 に示されてい る. Table 4 の数値については, 上述と同じ理由から，1 要因分散分析を行なった結果有意差がみられた $\left(F_{(2,97)}\right.$ $=177.56, p<.001)$. 従って，この有意な変動がどの反 応様式群間に見出されたのかを検定するために Tukey testを行なった. その結果, 概念的反応様式群と連合的 反応様式群との間 $(p<.001)$, 逆反応様式群と連合的反 応様式群の間 $(p<.001)$ に有意差がみられ. 概念的反応 様式群は連合的反応様式群よりも, また逆反応様式群は 連合的反応様式群よりも学習が容易であった。一方, 一 種の媒介反応椂式とみなされる逆反応様式群と概念的反 応様式群との間には有意差はみられず, 両群は注ぼ同じ 速度で学習していたことが示された.

\section{考察}

本研究では, 課題構造の把握を促進するような先行教 示条件（P群， V 群， $\mathrm{PV}$ 群）が与えられることによっ て被験者の情報処理の水準がどのように異なり，またそ れが逆転移行過程での反応様式にどのように反映される かを問題にした. この点に関する実験結果は，3実験群 ( $\mathrm{P}, \mathrm{V}, \mathrm{PV}$ 群) と統制群 ( $\mathrm{C}$ 群) の反応様式の頻度パタ ーンならびに反応速度を比較することによって得られ る.

Table 2 から明らかなよらに，実験者の意図している 課題構造把握への方向に注意を向けるよらに十分な先行 教示条件の与えられた PV 群は， C群よりも概念的反応 様式を有意に多く利用しているし, 逆にC群では, 逆反 応様式や連合的反応様式が半数以上みられている. この 結果は, 予測を満足するものであり, 次のように解釈さ れよう. 本実験での課題の適切次元が知覚的側面（色・ 形）といら特殊的なものであるためにC 群にとっては, 課題がかなり困難である.すなわち, 単語の持つ仮説, イメージの豊富さ, 内容の差異のために, 被験者がそれ ぞれの単語から引き出す仮説, イメージと, 実験者の意 図している仮説（適切次元）とがなかなか一致しない. そのために C 群では, 試行錯誤的行動のもとに, しかも 適切次元を抽出しえないうらに原学習が完成してしまう 可能性が大である. そのような情報処理水準にある時 に, 移行課題が与えられると, 当然, 次元性を媒介子々 した概念的反応様式を利用することが困難であり, 強化 された刺激単語を $1 つ 1 つ$ 覚え弁別していくといった連 合的反応様式や，別の逆反応様式をとらざるを得なくな る. 一方, 実験者が意図している適切次元を識別同定で さる方向に注意を集中するよらな先行教示条件が与えら れた PV 群は, それを1つの手がかりとして原学習課題 を遂行する（すなわち, 実験者の意図している仮説検証 行動のもとに学習する）ことが可能になる. そのために 原学習完成時には, 多くの者が, 何が適切次元で, 何が
不適切次元であるかを十分に分化識別できるまで情報処 理の水準が進行していたと又られる.ゆえに移行過程に 扣いては，その抽出した適切次元を媒介子とした効率の よい概念的反応様式を容易に利用することが可能であっ たといえよう。な掠 PV 群と同じように，先行教示条件 の与えられた $\mathrm{P}$ 群やV 群も，それぞれC群よりも概念的 反応様式を多く利用していることがデータ上からは観測 されるが，統計的には有意でなかった，ここで，“ $\mathrm{P}$ 群 やV群が，なぜ C群よりも有意に多く概念的反応様式を 利用しえなかったのであろらか”という問題が生じてく るが解釈が困難である、しかしながら，一応，次のよう に考えることができよう，PやVでけといった先行教示 条件では, 課題構造を認知するためにはまだ不十分であ ったのではないか.すなわら, 学習前に, 単に刺激単語 の描画を提示したりなならのフィードバックなしに 刺激語の特殊なイメージを思い出させる教示を与えたと しても, 学兒過程時の反応をコントロールするほど十分 な課題構造把握への樽えが形成されないといらことであ る. そのため原学習終了時の情報処理の水準が, 適切次 元抽出の段階まで十分に達しなかったものと思われる.

従って，C群よりも有意に概念的反応様式利用者が増加 しなかったといえる.このように解釈してくると，Pと Vの 2 要因の相乗作用をまってはじめて, 概念的媒介者 は活性化されると想定できよう。

ところで，これまでは逆転移行過程での反応様式が先 行教示条件の羑異によって，どのように異なるかについ て考えてきたが，先行教示条件の差異は，また原学習， 移行学習での成績にも反映されている，すなわち，これ までの解釈から予想されるように, 原学習課題に和いて は, PV 群は有意にC 群よりも学習が容易であったが, $\mathrm{P}$ 群と $\mathrm{C}$ 群, かつ $\mathrm{V}$ 群と $\mathrm{C}$ 群の間には, 有意な変動が観 測されなかった.これらの結果は, 学習過程での反応を コントロールできるほど, 先行教示条件によって課題構 造が把握されていたか否かを反映しているといえよう. 一方, 移行学習での学習速度の差異に関する解釉は, 原 学習時のそれとは，少し趣が異なる。なぜなら，この段 階での学習速度の差異には, 先行教示条件の効果にとも なら原学習完成時の情報処理水準の効果が主に反映され ていると考兄られるからである. そこで，もし媒介反応 様式は学習の経済性を高めると仮定されるならば, 移行 学習課題での成績は, 最も能率のよい媒介反応様式を多 く利用できた群ほど容易であることが予測される。実 際，この段階での成績は，媒介反応様式（概念的反応様 式十逆反応様式 $)^{5}$ が多く見られた群, すなわら PV 群, $\mathrm{V}$ 群, P 群, C 群の順に容易であった（それぞれの順に 1. 45, 1.77, 1.91, 2.55, Table 1, 2 参照). 統計的に も $\mathrm{PV}$ 群はC 群よりも, $\mathrm{V}$ 群はC 群よりも, $\mathrm{P}$ 群はC 群 よりも学習が容易であることが示された. これらの結果 
は上述の仮定ならびに予測を満足するものであり，移行 課題での学習速度の差異は, 媒介反応様式の頻度の差異 と相関していると結論つけられる。先に Maruno (1974, 1975 b) は，移行過程時に被験者がぞのような反応様式を 利用するかは, 原学習完成時の情報処理の水準によって 異なることを示晙したが，そのことは，また，移行課題 での学習速度についてもいえることを，これらの結果は 示している.

一方, 反応様式の学習に拈よぼす有効性に関しては, 本研究に特いても, Maruno (1974, 1975 b) と同じよう な結果が確認された. すなわち, 原学習課題に特いては, 概念的反応様式群は連合的, 逆反応様式群よりも学習が 容易であり，かつ後者 2 群間には有意差がみられない (Table 3 参照). しかし, 移行学習課題に括いては, 概 念的, 逆反応様式群は連合的反応様式群よりも学習が容 易であり，かつ前者 2 群間には有意差はみられなかった (Table 4 参照). これらの事実は, 逆反応様式は概念的 反応様式と同じように一種の媒介反応様式とみなされる こと（強いて両者の差異を示せば，後者は次元性 (or 上 位，共通概念）を媒介子とした媒介反応様式であるが， 前者は主体的に形成したセット or ユニットを媒介子と した媒介反応様式といえよう)，充，被験者は逆転移 行過程に执いて 3 反応様式（概念的，逆反応，連合的反 応様式）のどれかを利用可能であることを暗示してい る.

最後に，本実験の結果ならびに結果に対する解釈は， 仮説検証行動のメカニズムを説明するために提案した Levine (1974) の転移仮説 (The transfer hypothesis) によく一致している.この仮説によると，被験者は，そ れまで強化されていた刺激が誤反応になると他の仮説領 域（ここでの仮説は本実騟での次元あるいは，セットに 対応）の刺激を選択するよりもまず初めに同仮説領域の 残りの刺激を選択すると仮定されている.しかしなが ら，移行過程に和いて被験者がそのよらな仮説検証行動 を行ならためには，学習課題が含んでいる全仮説 (The hypothesis universe) が，原学習終了段階に和いては いくつかの下位仮説域 (Subdomains) に分化識別されて いなければならない、すなわち，本実験のように学習課 題が 2 次元を含む 8 つの単純仮説 (Simple hypothesis)

5 Maruno $(1974,1975$ b) は, 逆反応様式も一種の媒介 反応様式であるということを，その機能的側面（原学習 で形成したセット関係（正刺激セットと負刺激セット） を移行学習でも維持できる。そこでは，ただ強化パター ンだけが原学習とまったく逆になる)と実際のデータ（原 学習に招いては連合的反応椂式群と同じよ5な速度で学 是するが，移行学習に扣いては連合的反応様式群よりも 容易に学習するが，概念的反応様式群との間には有意差 がみられない）から示した。
からなる場合，原学習終了時には，少なくとも 2 つの下 位仮説域（共通次元を抽出しているか, 共通刺激セット （強化, 非強化刺激セット）形成の段階にあるかは別と して）が認知されていなければいけないし，もしそらで なければ, 当然, 移行課題に和いても原学習課題と同じ ように S-R 的な試行錯誤的行動様式をとらざるをえなく なる. Maruno (1974, 1975 b) ならびに本実験で示され た, 概念的, 逆反応様式群は連合的反応様式群よりも移 行課題が容易であったが前 2 者間には有意差がみられな かったという事実と, 移行過程での反応様式は原学習終 了段階での情報処理水準に低存しているといら事実は, まさにこの転移仮説からの予想に一致しているといえよ う.このよらに被験者側の学習様式に注目し, 弁別移行 課題を仮説検証行動という概念同定 (Concept identification）過程の立場から考えな扎してみると, 原学習課 題の持つ意味は, 被験者がぞの程度課題構造そ把握して いるかを査定することに，移行課題のとれは，ぬさに原 学習課題の処理水準にもとづきどのような学習様式を利 用しているかを查定することにあると仮定されよう.今 ここで仮定された立場と従来の発達的媒介理論との間に は, 当然, 様々な問題 (例えば, 発達的パーフォマンス の差異を反映しているのは, 学習場面にはいってくる時 被験者が所持している仮説数の差異なのか，それとも同 じ仮説内での, あるいは仮説間での反応転換速度の差異 なのかといら問題）が生じてくるが，それは今後の研究 課題として残された.

以上, 総括すると, 逆転移行過程に执いて, どのよう な反応様式が利用されるかは, 原学習完成時の被験者の 情報処理の水準（課題構造把握の程度）に依存している のではないか（被験者の内省報告がこれを裏づけてい る), また, 移行課題での学習は, 原学習完成時の情報 処理の水準を反映した媒介反応様式の出現頻度が多い群 汪ど容易であるが，その情報処理の水準は操作的に実験 条件を設定することによってある程度変えることが可能 であるといえる。

\section{要約}

本研究の目的は, 課題構造の把握を促進するような先 行教示条件 (言語教示群 : V 群, 絵画提示群 : P 群, 言 語教示十絵画提示群 : PV 群) が与えられることによっ て, 被験者の情報処理の水準がどのように異なり，また それが逆転移行過程での反応様式ならびに移行課題での パーフォマンスにどのように反映されるかを検討するこ とであった. 上述のよらな先行教示条件が与えられる実 験群は, 課題構造把握への構えが形成され, そのため実 験者の意図しているような仮説行動のもとに課題を遂行 することが可能になり, その結果, 移行過程では次元性 を媒介子とした媒介反応様式を利用する被験者が多いで 
あろらと予想された。被験者は中学 2 年生 100 名で, 実 験材料は 2 次元（色・形）を同時に含んだ言語材料であ った．原学習，移行学習が終了した後，被験者は，どの ように情報処理していったか，あるいは適切次元を同定 できたかどらかを，いくつかの質問項目のもとにその内 省報告を求めて決めた。主な結果は次の通りであった。

1. $\mathrm{PV}$ 群にはC 群（統制群：先行教示なし）よりも 概念的反応様式利用者が有意に多くみられたが，逆にC 群には PV 群よりも連合的反応様式利用者が多くみられ た。

2. $\mathrm{P}$ 群と $\mathrm{V}$ 群にも，C群にくらべ，概念的反応様式 利用者が多いことが資料上から視察されたが有意差はみ られなかった。

3. 学習速度にも先行教示条件の効果がみられ, 特に 移行課題では，効率的な媒介反応様式の利用者が多い群 ほぞ（順に PV 群， V 群， P群， C 群) 学習が容易であ った。

4. 原学習に预いて, 概念的反応樣式群は逆反応, 連 合的反応様式群よりも学習が容易であったが, 後 2 群間 には有意差はみられなかった。一方, 移行学習課題に拉 いては，概念的，逆反応栏式群は連合的反応様式群より も学習が容易であったが，前 2 群間には有意差はなかっ た.

以上の結果は, 被験者の関数としての情報処理の水準 といら観点から考察され, 被験者が移行過程において, どのような反応様式を利用するかは原学習終了段階での 情報処理の水準に依存して扣り, また移行課題での学習 速度は効率的な媒介反応様式の出現頻度に関係している ことが結論づけられた。 このように移行過程での反応様 式ならびに移行課題での学習速度におよぼす原学習終了 段階での情報処理の水準の重要性が考慮されたが，その 水準は，実験的操作によってある程度変えることが可能
であることが示唆された.

\section{引用 文 献}

Bogartz, W. 1965 Effects of reversal and nonreversal with CVC stimuli. Journal of Verbal Learning and Verbal Behavior, 4, 484-488.

Cole, M. 1973 A developmental study of factors influencing discrimination transfer. Journal of Experimental Child Psychology, 16, 126-147.

Goulet, L. R., \& Williams, K. G. 1970 Children's shift performance in the absence of dimensionality and a learned representational response. Journal of Experimental Child Psychology, 10, 287-294.

Kendler, T.S., \& Kendler, H. H. 1970 An ontogeny of optional shift behavior. Child Development, 41, $1-27$.

Levine, M. 1974 A transfer hypothesis, whereby learning-to-learn, Einstallung, the PREE, reversalnonreversal shifts, and other curiosities are elucidated. In R. L. Solso (Ed.), Theories in cognitive psychology: The Loyola symposium. John Wiley \& Sons. Pp. 289-303.

丸野俊一 1973 言語材料による逆転, 非逆転移行学習 心理学研究, 44, 141-149.

Maruno, S. 1974 Strategies in reversal and nonreversal shifts learning. Japanese Psychological Research, 16, 99-105.

丸野俊一 1975 a 移行学習の習得過程に和ける概念的 方略の分析一次元内移行 (HOS) 子次元外移行 (HES) の比較に和いて——理学研究，46, 1-9.

Maruno, S. 1975 b Developmental changes of strategies in reversal shift process. Japanese Psychological Research, 17, 167-173.

- 1975. 7. 3. 受稿— 


\section{SUMMARY}

The present study was designed to analyze the effect of mediation-generative instructions upon the performance and learning modes in reversal shift. Prior-instructions (conditions) which increase the likelihood isolating and utilizing the stimulus dimensions were given $S$ s as follows: (a) Instructions to generate a visual image of the stimulus pair member (Verbal), (b) presentation of the picture of the stimulus pair member (Pictorial), (c) the presentation and the instructions were given together (Pictorial-Verbal) or (d) neither Pictorial nor Verbal instructions were given (Control). 100 junior high school students were given reversal shift with verbal materials containing two dimensions simultaneously. After the shift problem was completed, the level of information-processing of $S \mathrm{~s}$ was determined by some questions designed to see whether the common concept was identified. Depending upon the assessed level of information-processing $S \mathrm{~s}$ were classified into the following three groups : (1) Conceptual learning mode group, the members of which could utilize the common concept, (2) responseswitching learning mode group, the member of which reported the use of a rule such as "doing the opposite" without utilizing the common concept, and (3) associative learning mode group, the members of which picked up the correct reinforced word one by one with- out utilizing the common concept or using a rule such as "doing the opposite".

The main results were as follows: (1) In the Pictorial-Verbal, Verbal, Pictorial groups (in order), the mediational mode responses (conceptual, response-switching learning mode) were found more numerous than the associative learning mode, while in the Control group the inverse was true. (2) In the group that efficient mediational mode responses were found more numerous (in order, Pictorial-Verbal, Verbal, Pictorial, Control groups), the shift problem was easy. (3) In the original problem, the conceptual learning mode group learned faster than both the response-switching and associative learning mode groups, but there was no significant difference between the response-switching and associative learning mode groups. (4) In the ishift problem, both the conceptual and response-switching learning mode groups learned faster than the associative learning mode group, but there was no significant difference between the conceptual and response-switching learning mode groups.

From these findings, it was suggested that whichever learning mode $S$ s utilize in the reversal shift process depends upon the depth of information-processing at the end of original problem, and the speed of learning in the shift problem depends upon the frequency of an efficient mediational mode. 